\title{
ITPR2 wt Allele
}

National Cancer Institute

\section{Source}

National Cancer Institute. ITPR2 wt Allele. NCI Thesaurus. Code C114577.

Human ITPR2 wild-type allele is located in the vicinity of $12 \mathrm{p} 11$ and is approximately 498

$\mathrm{kb}$ in length. This allele, which encodes inositol 1,4,5-trisphosphate receptor type 2

protein, is involved in intracellular calcium release. 